\author{
Mągorzata M. Ptak, Miroseaw J. Śmiatek \\ Uniwersytet im. Adama Mickiewicza \\ w Poznaniu
}

\title{
OSOBA NAUCZYCIELA WOBEC PATOLOGII W PRZESTRZENI EDUKACYJNEJ
}

\begin{abstract}
Ptak Małgorzata M., Śmiałek Mirosław J., Osoba nauczyciela wobec patologii w przestrzeni edukacyjnej [Teacher vs Educational Disfunction]. Studia Edukacyjne nr 50, 2018, Poznań 2018, pp. 289306. Adam Mickiewicz University Press. ISSN 1233-6688. DOI: 10.14746/ se.2018.50.19

In modern education, a personal attitude towards a teacher defines their mission in education. Equally important is an understanding of one's subjectivity as a human being and the importance of others in life-long learning, more widely perceived as the growth of humanity. The role of teachers and their educational mission are faced with a number of dynamic dysfunctions, which effectively challenge their ability of achieving teaching career goals, especially through the prism of leadership within education.
\end{abstract}

Key words: teacher, subjectivity, education, educational dysfunction, leadership

Nauczyciel jako osoba powinien potrafić sobą kierować, rozumieć ciągłość między przeszłością, teraźniejszością i przyszłością w różnych wyborach oraz podejmowaniu decyzji. Z powołania nauczyciela powinno i wynika takie zarządzanie rzeczami, by służyły wspólnemu dobru. Dotyczy to nade wszystko dążenia do prawdy, dobra i piękna, jak również oznacza kierowanie się nie tyle własnym interesem, co dobrem innych. Podobne odczucia towarzyszą spełnianiu powinności nauczyciela jako osoby, które mają ścisły związek z wolnością i chronią osobę przed nieuprawnioną ingerencją z zewnątrz. Dzięki temu osoba może nie tylko dostrzegać, ale nade wszystko akceptować obowiązujące normy życia społecznego ${ }^{1}$. Osoba ta jest zdolna do określonego działania $w$ aktach poznania, wolności i odpowiedzialności. $W$ ten sposób wyraża swoją duchową i wewnętrzną wolność, której osiąganie jest obowiązkiem każdego człowieka jako osoby. Pozwala to osobie przekraczać samą siebie i kierować się ku transcendencji. Właściwości te umożliwiają budowanie

${ }^{1}$ Z. Marek SJ, Pedagogika towarzyszenia, Kraków 2017, s. 136-137. 
relacji międzyosobowych, łączących osobę z naturą, kulturą i transcendencją, dając pełniejsze poznanie istoty człowieczeństwa, wzrastania w człowieczeństwie, opartego na trzech źródłowych pytaniach: „kim jest człowiek?”, ,"kim staje się człowiek?” i „kim ma być człowiek?”2.

Dynamika współczesnej edukacji sprawia, że pedagodzy stawiają coraz trudniejsze pytania wynikające $\mathrm{z}$ przestrzeni obecności pedagogiki w polskiej szkole. Analizując edukacyjną komunikację interpersonalną w zróżnicowanych kulturowo społecznościach uczniów i nauczycieli, podkreślają oni wagę uzyskania pedagogicznego kompromisu, akceptowanego przez te grupy. Obecność w środowisku pedagogicznym błędów wychowawczych i dydaktycznych, w świetle przywództwa edukacyjnego, zyskuje u nauczycieli wymiar zasady twórczego wykorzystania niepowodzeń własnych i uczniów, by dawać sobie z nimi radę, jak te niepowodzenia rozumieć. Znajomość praw Yerkesa - Dodsona, respektowanych w tolerowaniu indywidualności ucznia i wyzwalaniu u niego twórczego entuzjazmu, pozwala mądrze sterować procesami motywacyjnymi także u nauczyciela. Umiejętności komunikacji interpersonalnej w przywództwie nie są wolne od błędów przy formułowania poglądów czy podejmowaniu decyzji. Błąd jest najbardziej ludzką cechą, ponieważ w pewnych sytuacjach pozwala szybciej podejmować, a nawet zmieniać decyzje (efekt skupienia), pomimo że korzyści są szkodliwe. Najtrudniejszy z nich jest wychowawczy błąd poznawczy. Swoją genezę posiada $\mathrm{w}$ tak zwanym błędnym spostrzeganiu społecznym, wynikającym z „nieświadomego upraszczania poznania i zrozumienia otaczającej rzeczywistości" ${ }^{3}$. W literaturze wymienia się szereg błędów, klasyfikując je jako błędy indywidualne oraz w tak zwanej sztuce oceniania. Są to błędy: projekcji, atrybucji, łagodności, surowości, trwałości ocen, tendencji centralnej, aureoli, hierarchii, kontrastu, pierwszego wrażenia, ostatnich dokonań ${ }^{4}$, które widoczne lub bezpośrednio niedostrzegalne prowadzą do zaburzenia procesu wychowania, relacji pomiędzy wychowawcą a wychowankiem. Takie zakłócenia (zerwanie lub rozpad) wychowawcze mają wpływ na inne sytuacje, w innych przestrzeniach życiowych dziecka, gdyż mogą stanowić realną przyczynę (a nawet ryzyko) powstawania szkodliwych dla rozwoju wychowanka skutków ${ }^{5}$. Niezależnie od wymiaru przestrzeni edukacyjnej i edukowanej błędy wychowawcze najczęściej przyjmują postać błędnych zachowań, które A. Gurycka uogólnia jako powszechne i niezależne od środowiska społeczno-kulturowego. Należą do nich: „ry-

2 Tamże, s. 138.

3 A. Ludwiczyński, Wdrażanie ocen pracowniczych, [w:] Zarządzanie zasobami ludzkimi, red. H. Król, A. Ludwiczyński, Warszawa 2007, s. 308-309.

4 Tamże.

5 A. Gurycka, Błąd w wychowaniu, Warszawa 1990, s. 24. 
goryzm, agresja, hamowanie aktywności, obojętność, eksponowanie siebie, uleganie (bezradność), zastępowanie (wyręczanie), idealizacja oraz tzw. błąd pochodny"'. Są one zróżnicowane (nie)profesjonalizmem pedagogicznym, strukturą osobowościową, czynnikami sytuacyjno-ideologicznymi wychowawcy i wychowanka ${ }^{7}$. Postawy wychowawcze wynikające z życiowego doświadczenia nauczyciela warunkują spektrum redundacji pedagogicznej. Trudno wymienić wszystkie błędne zachowania pedagogiczne i decyzje wychowawcze podejmowane przez nauczycieli, jednak ważne jest zasygnalizowanie, że $w$ przestrzeni edukacyjnej każdy proces wychowawczy "dotykają" błędy poznawcze społecznego funkcjonowania8. Są to zasady: podczepienia (podążanie za tendencją myślową i działaniową grona pedagogicznego), skrzywienia zawodowego (monopol na poprawność oceny, wnioskowania, działania wobec uczniów), efektu ślepej plamki (iluzoryczność autooceny rzeczywistości - niedostrzegania własnych błędów wychowawczych), efektu posiadania (autoreklama kategorią dowartościowującą dydaktycznie i wychowawczo), efektu skupienia (najwyższe uznanie dla własnych działań i efektów wychowawczych), iluzji kontroli (każdego wychowanka, klasy, społeczności uczniowskiej), niechęci do straty (niepowodzenia wychowawcze zawsze mają pejoratywny wymiar), efektu czystej ekspozycji (maksymalne kopiowanie autorytetu zawodowego warunkiem własnego sukcesu i awansu), efektu pominięcia (gloryfikacja ślepego posłuszeństwa i jedności grupowej, z jednoczesną negacją indywidualnych poczynań), efektu status quo (pełna zgoda na niezmienialność), efektu izolacji (negatywność zapamiętywania każdych wyróżników wychowawczych), efektu obserwacji (nieświadome sugerowanie i pożądanie oczekiwań wychowawczych), efektu pewności wstecznej (każde niepowodzenie wychowawcze skomentowane sloganem: „wiedziałem, że tak będzie!”), zasada szczytu - końca (nie efektywność, ale efektowność wychowawcza - in plus $\mathrm{i}$ in minus jako impuls do dalszych działań) i zasada subkonfirmacji (dostrzeganie własnych efektów - tylko tych oczekiwanych, ignorując wskaźniki obiektywne).

Czynniki wpływające destrukcyjnie najczęściej określa się jako

błędy wychowawcze, czyli niewłaściwości w postępowaniu wychowawców (rodziców, nauczycieli, instytucji, środowisk) z dziećmi i młodzieżą w procesie ich rozwoju i wychowania. Błędy wychowawcze przejawiają się głównie w nieprawidłowych postawach dorosłych (zachowania się w roli wychowawcy), nieprzestrzeganiu lub łamaniu empirycznie ustalonych i zweryfikowanych w praktyce zasad pedagogicznego działania. Stosowanie takich metod oddziaływania na dzieci i młodzież prowadzi do

\footnotetext{
6 Tamże, s. 81-82.

7 E. Wysocka, Encyklopedia pedagogiczna XXI wieku, t. I, Warszawa 2003, s. 410.

8 T. Maruszewski, Psychologia poznania, Gdańsk 2001, s. 32-72.
} 
sytuacji sprzecznych z oczekiwaniami wychowawców, a także niezgodności z celami i zadaniami wychowania danej placówki9.

Destrukcję wychowawczą najczęściej stanowią zasoby „wiedzy milczącej" każdej placówki sformalizowanej, nastawionej na statystyczne rankingi i prestiż dydaktyczny. To wiedza trudna do zobrazowania w analizie badań ilościowych, bowiem ujawnia się w sytuacjach spontanicznych, w wypowiedziach i refleksji nieplanowanej, w sytuacyjności emocjonalnej. To wiedza najczęściej podbudowana doświadczeniem życiowo-zawodowym, bowiem przestrzeń edukacyjna i edukowana są kreowane także rygoryzmem, oczekiwaniami od uczniów pełnego posłuszeństwa, a nie kreatywności, hamowaniem uczniowskiej aktywności i obojętnością wobec jej pozytywnych przejawów, nieuwzględnianiem potrzeby indywidualizacji w procesie nauczania i wychowania, nieaktywnością i poniżaniem wychowanków w związku z ich niewiedzą i nieumiejętnościami, oskarżaniem i obwinianiem, moralizowaniem, agresją słowną i fizyczną, brakiem obiektywizmu i powszechną stronniczością, pociąganiem ucznia do odpowiedzialności za odmienność stanowiska jego rodziców bądź krytykę nauczyciela, brakiem przyjacielskich postaw wobec uczniów z jednocześnie niskim poziomem samokrytycyzmu ${ }^{10}$.

Może dlatego tak powszechnym zjawiskiem w przestrzeni edukacyjnej jest nieufność i kontrola!? Nauczyciele nie ufają swoim uczniom, udowadniając to dydaktycznie i wychowawczo stale obecną kontrolą. Nauczycieli zaś kontrolują ich jednostki nadrzędne i władze oświatowe. Postrzeganie kontroli jako działania korekcyjnego i korygującego sprawia, że nieufność świadomościowo była i jest uzasadniona. Kontrola generuje w osobach dwie postawy: tę oficjalną, przygotowaną na kontrolowanie (z przyzwoleniem emocjonalnym i aksjologicznym, najczęściej dotyczącym sfery zawodowej) i postawę prywatną (najczęściej nieakceptującą kontrolowania, a tym samym wyzwalającą u osób kontrolujących i kontrolowanych nieufność, zastrzeżenia, nadinterpretację, a więc szereg wyżej wymienionych zasad błędów wychowawczych). Kontrola i "towarzysząca jej” nieufność wychowawcza generują, niestety, bierność wychowawczą. Zachowania wychowawcze w sytuacjach kontrolowanych, ze względu na osoby lub czynniki kontrolujące, są najczęściej konformistyczne, a pozytywna aktywność wychowawcza dzieci i młodzieży najczęściej bardzo szybko uzależnia się od kontroli, wykluczając tym samym samorealizację i samowychowanie. Będąc instrumentem weryfikacji poprawności (mniej lub bardziej jawnej) dydaktyczno-wychowawczej w przestrzeni szkolnej, kontrola i nieufność stawiają grono pedagogiczne wo-

${ }^{9}$ H. Izdebska, Błędy wychowawcze, [w:] Encyklopedia pedagogiczna, red. W. Pomykało, Warszawa 1997, s. 47.

${ }^{10}$ K. Kruszko, Między uczniem a nauczycielem, Życie Szkoły, 2006, 1, s. 5. 
bec nacisku, który proces wychowania i jego wartości może łatwo przeobrazić w ideologię edukacyjną, a samych nauczycieli przeobrażać $\mathrm{w}$ decydentów nie tylko edukacyjnych, wskazujących jak należy żyć i wypełniać zobowiązania społeczno-kulturowe.

Życiowym sprawdzianem mądrej postawy osoby nauczyciela wobec patologii w edukacji jest umiar w kontrolowaniu i zdroworozsądkowej nieufności.

Zjawisko patologii najczęściej generowane jest ideologią. To ona w mniej lub bardziej subtelny sposób wpływa na określone typy relacji interpersonalnych. To ona generuje rozróżnienia "lepszy" / gorszy”, „ważniejszy” / "nieistotny" i skłania do instrumentalizacji stosunków między ludźmi. To klasyczne przesłanki do budowania przekonania o własnej wyjątkowości, o wyjątkowości własnych wartości i potrzeb lub deprecjonowania innych osób, ich wartości lub dążenia do osiągania celów. Funkcjonując w społecznościach o tak instrumentalnych relacjach interpersonalnych, bardzo łatwo samemu "zaszczepić" w sobie takie przedmiotowe traktowanie innych, postrzeganie innych ludzi w kategoriach użyteczności i doskonałe wykorzystywanie wszelkich technik manipulowania innymi. Zawód nauczyciela jest szczególnie podatny na "przesycenie” relacjami instrumentalnymi, instrumentalizacje procesu edukacji i instrumentalne postrzeganie uczniów. To makiawelizm dydaktyczny utożsamiany z autorytaryzmem, w którym partykularny cel awansu zawodowego niszczy podmiotowe relacje dorosłego z dzieckiem. W tej postaci ideologii dydaktycznej największe znaczenie uzyskują normy postępowania pod postacią ogólników obowiązujących wszystkich uczniów, niezależnie od wieku, klasy i pozycji szkolnej. To najczęściej zakazy i zalecenia zredagowane pod postacią regulaminu szkolnego, regulaminów klasowych, szkolnego programu wychowawczego i iluzorycznych praw kodeksu ucznia. Kategoryzacja tych norm, jako wyznaczników poprawności edukacyjnej, opiera się na prostej zasadzie systematycznego, bardzo częstego powtarzania. $W$ rezultacie, uczeń nabiera przekonania, że często słyszane hasła z regulaminu szkolnego lub kodeksu ucznia są bardzo ważne, mimo że najczęściej nie rozumie ważności danej szkolnej normy. Dla nauczyciela i ucznia (bowiem zasada ta obejmuje także nauczycieli, a może przede wszystkim nauczycieli!?) taka procedura socjalizacji lub indoktrynacji edukacyjnej, z punktu widzenia rozwoju społecznego i dojrzałości etycznej, jest wręcz destrukcyjna. Proces socjalizacji w przestrzeni edukacyjnej to proces uczenia się nowych form zachowania, modyfikacji już posiadanych i akceptacja dążeń innych osób. Jest procesem zamykania określonych ról i postaw $\mathrm{z}$ powodu przyjmowania nowych ról w nowych środowiskach lokalnych, akceptacji nowych wartości - najczęściej uznanych za standard społeczny, odpowiadających określonej kulturze - zamykania jednych dróg życiowych, 
przechodzenia na ścieżki życiowe innych napotkanych osób - najczęściej będących autorytetami - oraz otwierania nowych dróg poznawczych, emocjonalnych, etycznych oraz często uświadamiania ich rankingu w prestiżu społecznym.

Socjalizacja może mieć kierunek dyrektywny i aktywny. W wymiarze biernym sprzyja postawom odbiorczym, kształtuje w uczniach myślenie asymilacyjne bez kreatywności i innowacyjności, sprzyja bierności społecznej sprzyjającej konformizmowi i nonkonformizmowi. Wychowuje uczniów do pasywności poznawczej, zależnej od zaleceń i zadań nauczyciela, jego poziomu wiedzy przedmiotowej oraz poziomu autodyscypliny. To obecność ucznia, ale także i nauczyciela spolegliwego, posłusznie wykonujących każde zadanie edukacyjne zalecone przez dyrektora, przełożonego, wychowawcę i inną osobę dorosłą posiadającą prestiż społeczny. Niestety, obecność tak dyrektywnej edukacji często jest społecznie akceptowana, bowiem uzyskuje dobre efekty posłuszeństwa społecznego, gwarantuje osiągnięcie minimum wiedzy kulturowej, a w przypadku osoby nauczyciela jest gwarantem bezkolizyjnej (pedeutologicznie) realizacji wszystkich stopni awansu zawodowego. W takim kształcie edukacji przywództwo pedagogiczne ma znamiona tylko kierowania do i na określone dziedziny wiedzy oraz postawy i wzorce zachowań spełniające oczekiwania nauczycieli. Takie uzależnianie uczniów od postaw dorosłych generuje u samych nauczycieli najczęściej postawy autorytarne, modyfikujące liberalizm edukacyjny w kierunku kryteriów tylko i wyłącznie osiągania sukcesów dydaktycznych. To wychowanie opierające się na dominacji i władzy wykonawczej, w których nauczyciel dysponuje środkami mogącymi wpływać (przemocą lub groźbą przemocy) na zachowanie uczniów i reguluje to zachowanie wedle zamierzeń własnych lub dyrektora szkoły ${ }^{11}$. Drugi typ socjalizacji - aktywnej - umożliwia rozwój ucznia i jego nauczyciela w kierunku wolności podmiotowej i niezależności intelektualnej, bowiem kształtuje zdolność do podejmowania decyzji wraz z odpowiedzialnością za ich konsekwencje. Taka postawa generuje zróżnicowanie postaw i poglądów w określonym środowisku społecznym, tolerancję odmiennych punków widzenia, przyzwolenie na zachowania nietypowe - nieagresywne. To także wychowanie budujące relacje interpersonalne - altruistyczne, sprzyjające działaniom ograniczania dynamiki zjawisk agresji emocjonalnej, patologii personalnej i rewizjonizmu pedagogicznego.

Szkoła jest jedną z wielu przestrzeni życiowych, w mikroskali, w której nieustannie dokonują się wszelkie procesy i zjawiska symptomatyczne dla każdego środowiska społecznego. To przestrzeń edukacyjna, w której obok sukcesów są porażki: dydaktyczne i wychowawcze, rozwój i regres, asymi-

${ }^{11}$ L. Kołakowski, Mini wykłady o maxi sprawach, Kraków 2008, s. 12. 
lacja z indywidualizacją, kooperacja obok antagonizmów personalnych, budowanie nowych więzi emocjonalnych przy destrukcji już dokonanych. To pulsatory pedagogicznej przestrzeni, procesów społecznej obecności edukacyjnej, oświatowej, ekonomicznej i humanistycznej. A więc, jeśli społeczność szkolna doświadcza tak wielu oczywistych procesów społecznych, wobec tego obecność zjawisk patologicznych powinna być postrzegana jako norma społeczna, jako wartość kształcąca uczniów i nauczycieli. Które i jakie zjawiska patologiczne, w wymiarze przywództwa edukacyjnego, mogą stanowić o destrukcyjnym oddziaływaniu, a które z nich, oprócz braku wartości normatywnej, mają równocześnie pozytywny wymiar kształtujący dojrzałość społeczno-kulturową? Udział w tworzeniu sytuacji patologicznych mają przede wszystkim nauczyciele, choć oni także podlegają przemocy, doświadczają opresji. Próby budowania podmiotowych relacji z uczniami, dokonywane przez niektórych nauczycieli, w ogólnej liczbie grona pedagogicznego, giną $\mathrm{w}$ zinstytucjonalizowanej strukturze funkcjonowania każdej placówki oświatowej. Nauczyciele, niejako z obowiązku awansu, zdobywają kolejne dokumenty potwierdzające nowo zdobyte kwalifikacje (najczęściej pozostające jedynie na papierze), pracują coraz to nowszymi metodami, lecz nie potrafią wyzbyć się pozycji władzy nad uczniem, przewagi społecznej nad rodzica$\mathrm{mi}$, a swoją rolę opierają na przemocy symbolicznej, subtelnie sankcjonującej władzę w systemie edukacyjnym.

Szkoła jako instytucja społeczna, z tytułu specyficznej hierarchii stratyfikacyjnej stanowi doskonałe źródło społecznego generowania agresji i przemocy. Jest to uwarunkowane nie tylko bezpośrednim i widocznym niepoprawnym zachowaniem uczniów, ale także atmosferą w przestrzeni społeczno-symbolicznej i reakcją na obecność w nowej przestrzeni społecznej (adaptacja do i $z$ wybieraną oraz narzucaną rolą społeczną), jak również często z różnymi próbami przetrwania w szkolnej rzeczywistości. Zjawisko agresji nauczycieli wobec uczniów bywa sporadycznie opisywane w publikacjach pedeutologicznych, a w ocenie autorów tej publikacji jest ono w stopniu najwyższym odpowiedzialne za skalę i dynamikę patologii szkolnych.

W jakiej mierze współczesna szkoła jest dla uczniów, a w jakiej dla nauczycieli? Dla kogo uczniowie to niestety wartość przedmiotowa w edukacyjnej strukturze systemu oświaty? Pytanie jest zasadne w aspekcie praktycznego wymiaru współczesnej szkoły, w której tylko uczniowie wykonują polecenia nauczycieli, respektowany jest regulamin zredagowany tylko przez nauczycieli, obowiązuje dynamika zachowań fizycznych wyznaczona przez nauczycieli, a sami uczniowie mówią i pytają treścią oraz formą dostosowaną tylko dla nauczycieli! To dla nauczycieli, nieporadnych i nieśmiałych wychowawczo, w szkołach instalowane są kamery, które w perfekcyjny sposób uczą uczniów dwuznaczności, kształtowania świadomości koniunkturalizmu ról 
społecznych (tych widocznych/korzystnych i tych niewidocznych/nie zawsze opłacalnych), a więc ukrywania swojej indywidualności, a w konsekwencji kształtowania postaw „prawdy oficjalnej i prywatnej". Komu, we współczesnej szkole, potrzebne są mundurki...?, zapewne nie uczniom, którym odbierają indywidualność fizyczną, ujednolicają osobowość edukacyjno-społeczną, bowiem są sztucznie podtrzymywanymi reliktami szkół totalitarnych (wojskowych, wyznaniowych). Dlaczego współcześnie pracujący nauczyciele w szkole XXI wieku nie postrzegają agresji dzieci i młodzieży jako naturalnego czynnika adolescencji (dojrzewania biologiczno-społecznego), potrzebnego w kształtowaniu dojrzałości aksjologiczno-społecznej? Dlaczego agresja jest dla uczniów skalą doświadczanego dydaktycznego poniżenia i niesprawiedliwości dorosłych oraz miarą słabości nauczyciela w pedagogicznym niezrozumieniu dziecka? Dlaczego często symbolami polskiego nauczyciela nadal jest kreda i tablica?

Ciągle, dla wielu nauczycieli, te archaiczne symbole stanowią platformę ukrywania kompleksów niedostatecznej wiedzy i nieumiejętności. Niestety, stanowią także obronę przed szokującymi ich zachowaniami uczniów. Nieporadność nauczycieli przede wszystkim wynika z niewiedzy o sposobach reagowania na szokujące agresywne zachowania uczniów.

Co z tego, że skończyłam kilka kursów, uczyłam się sposobów porozumiewania $z$ uczniami, skoro w praktyce szkolnej jest to zupetnie nieprzydatne. Na kursach powinno nas się uczyć zachowania w sytuacjach ekstremalnych - reagowania na wulgaryzmy, pyskowanie, obraźliwe gesty. Ja nie umiem sobie radzić z chamstwem uczniów - nauczycielka liceum, 10 lat stażu pracy.

Uczniowie zastaniaja sie swoimi prawami jak tarcza i robia to, co chca. Czuja się nietykalni i bezkarni. Tak dalej być nie może! - nauczycielka gimnazjum, 6 lat pracy $^{12}$.

O stopniu i skali poczucia zagrożenia $\mathrm{w}$ środowisku nauczycieli, zjawiskach i agresywnych zachowaniach uczniów pewne pojęcie daje roczny Raport programu społecznego "Szkoła bez przemocy" $2009^{13}$ - w zdecydowanej części obrazujący nauczycielskie poczucie doświadczanej przemocy psychicznej (obrażanie nauczyciela, ignorowanie jego poleceń, prowokowanie do wybuchów złości). Zastanawia jednak zróżnicowanie uczniowskiej i nauczycielskiej oceny stopnia radzenia sobie z tego typu zachowaniami, bowiem 36\% uczniów twierdzi, że szkoła zupełnie nie potrafi znaleźć rozwiązania kompromisowego na obecną agresję uczniowską, gdy tymczasem na analogiczne pytanie $90 \%$ nauczycieli odpowiedziało, że bardzo dobrze lub

12 J. Lubowiecka, Wielowymiarowe konteksty zawodowej roli nauczyciela, [w:] Nauczyciel i uczeń w przestrzeniach szkoty, red. M. Nowicka, Olsztyn 2002, s. 115.

${ }_{13}$ Raport programu społecznego Szkoła bez przemocy. Raport roczny 2009, http://www. szkolabezprzemocy.pl/pliki/176-raport-roczny-2009.pdf, [dostęp: 27.11.2018]. 
dobrze sobie radzi. Skąd zatem takie wysokie zróżnicowanie? Czy dlatego, że przemoc w szkole była, jest i zawsze będzie, a sami nauczyciele bardzo szybko adaptują się do nowych, uczniowskich zachowań agresywnych, przyjmując je jako stały społeczny element przestrzeni edukacyjnej? Może przyczyna tkwi w bardzo rzadko podejmowanych działaniach profilaktycznych, z tytułu braku u nauczycieli umiejętności mediacji społecznej, międzypokoleniowej? Konflikty, choć są naturalną częścią życia, trzeba umieć rozwiązywać, a w przestrzeni szkolnej mogą uzyskiwać także wymiar wychowawczy dla uczniów i nauczycieli.

Coraz częściej ujawnia się oczywista zależność pedagogiczna - im mniejszy autorytet nauczyciela, tym bardziej w działania wychowawczo-dydaktyczne nauczyciela wnika instrumentalne traktowanie uczniów, których opresyjne zachowania dynamizują się. Instrumentalizacja stosunków interpersonalnych znajduje swoje odzwierciedlenie w znikaniu z powszechnego słownika pedagogicznego takich kategorii, jak: dobry, wartościowy uczeń, czy uczeń zastugujący na ..., a na ich miejsce wchodzą określenia: nauczyciel/ uсzеń przydatny, mój uczeń/nauczyciel, tego ucznia/nauczyciela można użyć do ..., zauważyła M. Dudzikowa ${ }^{14}$ i dawno już monitowała, że w dzienniczkach ucznia nauczyciele wpisują tylko uwagi negatywne, krytyczne, oceniające, a nie zachwalające, gratulujące, pocieszające, wyróżniające .... Brakuje uwag typu: z satysfakcja informuje, iż syn Państwa zastuguje na pochwałe, ponieważ..., które w sposób fenomenalny dowartościowują każdego ucznia, pomagają mu odnajdywać jego mocne strony. Ich sporadyczna obecność jest wynikiem patologii szkolnej, usankcjonowanej prawem oświatowym, na mocy którego to tylko i wyłącznie dziecko zawsze jest winne nauczycielowi i szkole, gdy nie wywiązuje się ze swoich uczniowskich zobowiązań, natomiast jeśli swojej powinności nie wypełnia szkoła lub nauczyciel pozostają bezkarni, nie są dziecku nic winni. Przewidziano bardzo surowe kary dla złych uczniów, ale za bycie złym nauczycielom nie groża żadne sankcje ${ }^{15}$. Już niewielu nauczycieli zauważa u siebie specyficzną systematykę dotyczącą pracy wychowawczej, to jest nagminne wpisywanie uczniom uwag, przyznawanie punktów karnych za to, że na przykład zachowanie ucznia odbiega od przyjętej normy (ideału szkolnego), że jest zbyt żywy lub ospały, że nie nadąża z dynamiką poznawania nowej wiedzy wyznaczoną przez nauczyciela, że afirmuje swój bunt nawet wtedy, gdy nauczycielowi zabraknie cierpliwości. Jak pisze F. Dyka, brak tolerancji wobec dziecięcych figlów i psot czyni nauczyciela chłodnym moralistą, sumiennym nadzorcą, nielubianym przez dzieci, które za ciągłe uwagi i zrzędzenie starają się wyprowadzić go z równowagi ${ }^{16}$.

\footnotetext{
14 M. Dudzikowa, O trudnej sztuce tworzenia samego siebie, Warszawa 1985, s. 241.

15 J. Lubowiecka, Wielowymiarowe konteksty, s. 140.

16 F. Dyka, Osobowość nauczyciela wychowawcy, Edukacja i Dialog, 1999, 3, s. 41.
} 
Taka postawa w świetle literatury współcześnie określana jest przedmiotową realizacją pedagogicznego posłannictwa, to tendencja podporządkowywania swoich uczniów nauczycielskim poleceniom niepodważalnym i niekwestionowanym, to konstruowanie w świadomości uczniów hierarchicznego obrazu świata i obecności społecznych ról - odgórnie zadecydowanych i przyznawanych. Jakakolwiek postać uczniowskiej niezgody, zastrzeżeń i prób kwestionowania, w opinii uprzedmiotowionego nauczyciela, jest wyrazem nieposłuszeństwa, złamaniem obowiązujących zasad wywołujących dysonans, zaburzających ład edukacyjny i społeczny środowiska szkolnego. Takie przedmiotowe postrzeganie naturalnej indywidualności dzieci i młodzieży, w świadomości tak nauczającego nauczyciela, nigdy nie uzyska statusu pedagogicznego lustra, które najpełniej staje się podmiotowym drogowskazem pedeutologicznej kreatywności i edukacyjnej innowacji. Powszechność tego pedagogicznego standardu przedmiotowego w szkołach publicznych doskonale ugruntowuje dydaktyzm zamknięty na dialog i rozmowę - czyli nie jako samodzielne, indywidualne rozumienie i dochodzenie do wiedzy, lecz przyswajanie gotowej wiedzy i nagradzanie mądrego przyswajania wiedzy.

Wielu pedagogów, od kilku lat intensywnie „penetrujących” środowisko edukacyjne pod względem (nie)fizycznej agresji nauczycieli, potwierdza powszechność zjawiska agresywnych postaw nauczających nauczycieli. Warte przytoczenia są wyniki badań przeprowadzonych pod kierunkiem J. Obuchowskiej ${ }^{17}$, które w sposób jednoznaczny i niekwestionowany obnażyły wielopoziomowość agresji nauczycielskiej, a przede wszystkim osoby dorosłej wobec niezrozumienia pokolenia młodzieży i dzieci. W szkołach zawodowych na porządku dziennym uczniowie doświadczali słownego zastraszania, gróźb i wyzwisk, odpłacając się nauczającym ich nauczycielom także groźbami, złośliwymi komentarzami, groźbami pobicia, a nawet wybijaniem szyb. Kompetencje nauczających nauczycieli były podważane nie tylko przez agresywność emocjonalną uczniów, ale także przez rutynę i brak otwartości na innowacje, obowiązek sztywnego przestrzegania regulaminu zdominowanego drobiazgowością i rygoryzmem, a nade wszystko systematycznym udowadnianiem władzy ${ }^{18}$. Bezradność w sytuacjach konfliktowych, w opinii uczniów, nauczyciele najczęściej tuszują przemocą i zastraszaniem, wykluczającymi z procesu dydaktyczno-wychowawczego współpracę i emocjonalne bezpieczeństwo uczniów, tak bardzo nieodzowne dla prawidłowego funkcjonowania procesu dojrzałości szkolnej i społecznej. Przykre, że popularna jest taka opinia uczniów o nauczających ich nauczycielach, niebędą-

${ }_{17} \mathrm{~J}$. Obuchowska, Dynamika nerwic. Psychologiczne aspekty zaburzeń nerwicowych u dzieci i młodzieży, Warszawa 1983, s. 75.

${ }_{18}$ M. Dąbrowska-Bąk, Przemoc w szkole: analiza wychowania opresyjnego, Poznań 1995, s. 29. 
cych osobami, od których mogą uczyć się kultury osobistej ${ }^{19}$. Wyniki badań J. Obuchowskiej wystawiają nauczającym nauczycielom (u ponad połowy badanych uczniów) niechlubną opinię niesprawiedliwego oceniania uczniów, prowadzenia nudnych lekcji za pomocą metod utrudniających rozumienie nowo poznawanej wiedzy i częstego stosowania krzyku jako podstawowego środka komunikacji werbalnej z milczącymi uczniami. Właśnie takie sytuacje rodzą w uczniu szkolny lęk, obawy przed (przecież naturalnymi i potrzebnymi!) niepowodzeniami szkolnymi i rywalizacją między uczniami o wiedzę, rolę społeczną i rywalizację z nauczającym nauczycielem - rywalizację twórczą, kształtującą kreatywność i jeszcze bardziej pobudzającą ciekawość poznawania świata ${ }^{20}$. Nic tak destrukcyjnie nie oddziałuje na ucznia, nie rujnuje jego poczucia własnej wartości, jak brak u nauczającego nauczyciela akceptacji jego zindywidualizowanych uzdolnień, umiejętności, a także nieumiejętności i braku uzdolnień. To te braki najczęściej są źródłem antyspołecznych zachowań w środowisku uczniowskim, w którym agresja pozwala obniżyć lub rozładować generowane napięcie emocjonalne. Czy można (i należy) wymagać od ucznia mądrej postawy wobec powszechności: publicznej krytyki przed całą klasą (31,46\%), obraźliwych określeń osoby ucznia typu idiota lub kretyn $(28,09 \%)$, wyśmiewania ucznia w przypadku błędnie udzielanej odpowiedzi $(19,1 \%)$, czy wyszydzania wyglądu ucznia $(6,74 \%)^{21}$ ? Z bilansu wyników wielu badań ${ }^{22}$ wyłaniają się najczęściej występujące i akcentowane przez uczniów cechy niepożądane u nauczających nauczycieli:

1) niesprawiedliwość - najczęściej dotykająca oceniania uczniów, wyzwalająca u nich negatywne emocje, bowiem powinna dotyczyć oceny faktycznego stanu wiedzy ucznia a nie jego poglądów, stroju, a nawet płci;

2) złośliwość - najczęściej wymieniana i najboleśniejsza dla ucznia, w największym stopniu wyzwalająca w nim bezradność i chęć odreagowania;

3) faworyzowanie uczniów - cecha najbardziej niepożądana, bowiem argumentacja nauczycielska nie zawsze jest zgodna z powszechną opinią uczniowską;

4) ośmieszanie - stanowiące w opinii uczniów próbę tuszowania nauczycielskiej niekompetencji i kompleksów;

5) brak czasu dla uczniów - notoryczna obecność nauczycielskiego zniecierpliwienia brakiem u uczniów zrozumienia wykładanego tematu, zbyt powolnego (w ocenie nauczycieli) uczniowskiego odpowiadania przy tablicy, które jest jedną z najbardziej stresogennych sytuacji dla ucznia; nieustanna

${ }^{19}$ J. Lubowiecka, Wielowymiarowe konteksty, s. 115.

20 J. Obuchowska, Lęk szkolny, [w] Encyklopedia pedagogiczna, s. 137.

${ }^{21}$ S. Jochan, Zjawiska agresji i przemocy w klasach IV - VI szkoty podstawowej, Kalisz 2009.

${ }^{22}$ H. Gauzy-Steinke, Relacje nauczyciel - uczeń a norma wzajemności, Auxilium Sociale Novum, 2008, 1-2, s. 222. 
gonitwa i walka z czasem najczęściej krzywdzi dzieci uczące się i pracujące $\mathrm{w}$ wolniejszym tempie oraz generuje powierzchowność realizowanych przez nie zadań edukacyjnych;

6) bardzo powszechny brak poczucia humoru.

Obecność takich opinii obrazuje także kulturowe świadectwo nauczających nauczycieli. P. Mikiewicz ${ }^{23}$ (podając za D. Hargreavesem) określił je w sześciu elementach:

1) autonomii - metod i technik stosowanych w prowadzeniu lekcji i realizacji nowych treści; odbywa się to poza wiedzą i kontrolą innych nauczycieli;

2) lojalności - nie jest praktykowane ani pozytywnie oceniane wzajemne krytykowanie się przed dyrektorem lub uczniami;

3) przeciętności - nie należy do powszechnych chwalenie się nauczyciela własnymi osiągnięciami przed innymi nauczycielami oraz wyróżnianie ucznia na forum klasy za jego ciężką pracę lub szczególne osiągnięcia;

4) cynizmie - jako braku wiary w teoretycznie skonstruowane cele wychowawcze oraz w możliwość realizacji wprowadzania innowacji w strukturę szkolno-dydaktyczną;

5) antyintelektualizmie - widocznym w pragmatycznym stosunku do wykonywanej pracy postrzeganiu procesu nauczania i wychowywania jako tożsamego z procesem produkcyjnym, w tzw. pojęciu to tylko praca;

6) kategoryzowaniu - powszechnym i ulubionym przez nauczycieli etykietowaniu uczniów, z akceptacją obecności zniekształceń poznawczych (efekt Pigmaliona, Galatei, hallo, Golema itp.).

Oczywiście, zasadne wydaje się $\mathrm{w}$ tym miejscu wypunktowanie postaw uczniowskich, stanowiących odpowiedź, reakcję obronną na tego typu zachowania nauczycieli. Do najpowszechniejszych zalicza się: lizusostwo i inne reakcje schlebiające, uległość i przystosowywanie się, współzawodnictwo i rywalizacja $\mathrm{w}$ nurcie destruktywnym, powolne zanikanie tak zwanej komunikacji w górę, bunt i opór, tworzenie w środowisku klasowym sojuszów i koalicji oraz społeczne wycofywanie się i zajmowanie pozycji dystansu spoleczno-poznawczego.

Chyba nikt z nauczających nauczycieli nie przewidywał, że na tak zwanym szkolnym ringu agresji i przemocy uczniowsko-nauczycielskiej zostaną użyte przez młodzież narzędzia komunikacji medialnej, które dopiero w całej skali ukazują nie tylko efekty wzajemnej agresji, ale w analizie tych patologii szkolnych dopisują wiele treści kulturowo-społecznych, uświadamiających pedagogom ich złożoność i wieloaspektowość. Klasycznym przykładem jest tak zwana "sprawa toruńska”, w której bezradność nauczyciela, niekompe-

${ }^{23}$ P. Mikiewicz, Nauczyciel jako istotny aktor społecznego świata szkoty [w:] Nauczyciel: misja czy zawód? Spoteczne i profesjonalne aspekty ról, red. P. Rudnicki, B. Kutrowska, M. Nowak-Dziemianowicz, Wrocław 2008, s. 92. 
tencja, niemoc i lęk wygenerowały aspołeczne zachowania młodzieży. Historia tej patologii uświadomiła wielu pedagogom tylko teoretyczną obecność wszechobecnego hasła: zadaniem szkoty jest wychowywać a nie karać (!) oraz ograniczenia. To nauczyciel $w$ pierwszych kontaktach $\mathrm{z}$ klasą powinien wypracować czytelne dla uczniów zasady dotyczące pożądanego zachowania, spektrum wiedzy pożądanej i ocenianej, i umiejętności potwierdzających ową wiedzę. Bardzo ważna jest świadomość możliwości negocjacji tych zasad, wynikająca ze zmienności edukacyjnej i nieprzewidywalności wychowawczej. Ta swoista gra nauczyciela z uczniami często zostaje kierowana de facto na realizację tylko i wyłącznie zadań dydaktycznych, które promują i ugruntowują władzę nauczyciela nad uczniami, bez prawa do debaty, dialogu, konfrontacji merytorycznej niewiele umiejącego ucznia i najczęściej wszystko znajacego i wiedzacego nauczyciela.

Co lub kto stanowi o źródłach takich postaw? Zapewne jedną z licznych przyczyn jest wyobrażenie o roli i powinnościach nauczyciela piastującego funkcję dyrektora, który bardzo często skłonny jest myśleć, że wolno mu więcej niż pozostałym nauczycielom. To dyrektor szkoły preferujący, w strukturze powinności pedagogicznych, wartości: posłuszeństwa, przystosowania, uległości i spełniania zobowiązań najczęściej generuje u swoich nauczycieli postawy autokratyzmu wobec uczniów, upowszechniających wartości, których zobowiązani są sami przestrzegać. Takie kształtowanie pragmatycznych postaw prowadzi do uznawania w przestrzeni zawodowej i osobistej tylko wymiaru faktów, które mają wymiar fizyczny, zewnętrzności, rzeczywistego dowodu, prowadzą do kształtowania nauczyciela uprzedmiotowionego. Potwierdziły to wyniki badań B. Krzywosz-Rynkiewicz ${ }^{24}$, które unaoczniły wiele niespójności pedagogicznych między środowiskiem nauczycieli i uczniów. 20 dyrektorów szkół w ocenianiu swoich nauczycieli wykazało się ambiwalencją wobec idei pedagogicznych promowanych $w$ teoretycznych założeniach szkolnych programów wychowawczych i edukacyjnych.

We współczesnej pedagogice coraz częściej prezentowane są wyniki podobnych badań przeprowadzanych w środowisku akademickim. Kwestiami problematycznymi w praktyce akademickiej okazują się także obiektywizm, wzajemne poszanowanie poglądów, kultura interpersonalna oraz dojrzałość aksjologiczna. Studenci coraz głośniej krytycznie oceniają zbyt małe, ich zdaniem, zaangażowanie wykładowców w prowadzone zajęcia, sporadycznie zindywidualizowane podeście do studentów oraz nieciekawe metody prezentacji wiedzy. Współcześni studenci wielokrotnie zgłaszają zastrzeżenia wobec poziomu i kultury prowadzonych wykładów (ciche i niewyraźne mó-

${ }^{24}$ B. Krzywosz-Rynkiewicz, Ocena szkolna a ksztattowanie kompetencji zawodowych, [w:] Nauczyciel i uczeń w przestrzeniach szkoty, s. 145-153. 
wienie, brak spójności i logiki w prezentacji nowych zagadnień, wymagania wiedzy nieobecnej w literaturze obowiązującej) oraz brak u wykładowców sygnałów zwrotnych na zastrzeżenia artykułowane przez studentów.

Społeczeństwo zawsze utożsamiało zawód nauczyciela z kształceniem młodzieży do życia w społeczeństwie wiedzy i dynamizmów cywilizacyjnych. Od wielu pokoleń to nie rodzina, lecz nauczyciele są i powinni być społecznymi emisariuszami kulturowego kształtowania wszystkich młodych pokoleń. To od nauczycieli oczekuje się, że w sposób mądry i rzetelny będą przekazywać uczniom najistotniejsze paradygmaty społeczne: spektrum odpowiedzialności indywidualnej i grupowej; aksjomaty poczucia bezpieczeństwa i powszechności ryzyka życiowego; wymiar i istotę pracy jako zbiór czynności powtarzalnych i czynności twórczych (kreatywnych, innowacyjnych); spektrum adaptacji społecznej możliwej do modyfikowania i przekształcania; niuanse aksjologiczne między komfortem technologicznym a niezależnością i wolnością intelektualną oraz odwagę na myślenie przyszłościowe uwzględniające dziedzictwo i testament rodzinno-społeczny.

Między uczniem i nauczycielem nieustannie dokonuje się sprzężenie zwrotne $^{25}$, które ma swój wymiar w życzliwych postawach, przyjaznym odwzajemnianiu się oraz w nieżyczliwości, krytyce, braku zainteresowania, a czasem nawet wrogości. Brak pedagogicznej synergii pomiędzy treściami życzliwości i niechęci prowadzi do wielu sytuacji niepożądanych w szkole. Uczniowie, jako główni aktorzy szkolnej sceny, społeczną przestrzeń edukacyjną stale poddają relatywizacji, tworząc ją na nowo, konstruując na nowych poziomach opinie o pracujących nauczycielach dla innych uczniów i dla środowiska pozaszkolnego - lokalnego. Opinie te najczęściej mają wymiar czterech kategorii, w ramach których nauczyciele:

1) nakazują, dyscyplinują i bezkrytycznie wymagają;

2) tolerują uczniowski żart i śmiech;

3) w naukę wpisują śmiech i żart jako jeszcze jeden element edukacji, a prezentowaną wiedzę przekazują w sposób kompetentny, pamiętając, że emocje i zaangażowanie jedynie wzmacniają edukację;

4) dla uczniów są „przezroczyści” - wychowawczo, emocjonalnie, społecznie i aksjologicznie, tzn. „nie liczą się"; nie potrafią zapewnić na lekcji ładu (bezsilni wobec uczniów grających w karty, biegających po klasie, rzucających papierkami, naśmiewających się z niego), nie potrafią przyznać się do błędu, wykazując podczas lekcji znudzenie czy moralizowanie, lub użalanie się nad sobą samym.

Niestety, prorocze okazały się słowa A. Nalaskowskiego, że nauczyciele są materią i antymaterią edukacji, którzy choć pragnęliby zmienić pracę, bo

${ }^{25}$ H. Gauzy-Steinke, Relacje nauczyciel - uczeń, s. 223-224. 
wypalenie zawodowe czyni duże spustoszenie w ich aktywności społecznej, tkwią w swoich szkołach nieodwołalnie, nauczając - sami niewiele wiedząc. To społeczność skupiająca osoby o nieprzeciętnej charyzmie pedagogicznej, lecz także bezwiednie wypełniających nakazane im obowiązki, realizujących tylko i wyłącznie minimum programowe. A przecież, nauczyciel jako wykonawca cudzych pomysłów ma możliwość, społecznie wyjątkową, w treści programowe wpinać własne doświadczenie, kreatywność i innowację tak, by stawać się intelektualnym zapalnikiem dla swoich uczniów, pamiętając o heteronomii ${ }^{26}$, socjonomii ${ }^{27}$ i autonomii moralnej ${ }^{28}$ według J. Piageta. Niestety, pokazywanie dziecku rzeczywistości i nauczanie o niej wymaga dojrzałości społecznej. Jej wykładnikiem jest rozumienie, na czym polega istota wychowania - często mylona z dydaktyką, uczeniem z nauczaniem, a autorytet $\mathrm{z}$ autorytaryzmem. To szkoła jest najczęściej płaszczyzną styku kultury szkolnej, pochodzenia rodzinnego oraz środowiska lokalnego. Będąc instytucją społeczną, posiadającą czytelne normy i systemy wartości, porządkując zachowania i wzory relacji społecznych, wyznacza swoim uczestnikom spektrum dozwolonych relacji na swoim terenie, przyzwala na obecność jednostkowych różnic w środowisku uczniów i nauczycieli, wyznaczając tym samym treść tak zwanej kultury szkoły ${ }^{29}$, która umożliwia jej uczestnikom funkcjonowanie i pedagogiczny rozwój oraz społeczną integrację poprzez różne formy powiązań ${ }^{30}$. Tę kulturę budują i kształtują także opinie środo-

${ }^{26}$ Heteronomia moralna (2-9 r.ż.) - typowa dla zachowania regulowanego zakazem zewn. (sankcje zewn. - głównym powodem przestrzegania reguł moralnych), wyróżniamy: fazę egocentryzmu (2-5 r.ż., niezdolność rozumienia cudzych stanów psychicznych, własne emocje i dążenia projektowane na innych, zachowania asekuracyjne wobec kary i kierowane na pozyskiwanie nagród) i fazę konformizmu (5-9 r.ż., działania poszukujące podziwu, uznania innych, akceptacji, a pojawiający się stres wynika z konfliktu z wymogami moralnymi, wykształca się umiejętność oceny zachowania innych); http://pl.wikipedia.org/wiki/Rozw\%C3\%B3j_moralny, [dostęp: 27.11.2018].

27 Socjonomia moralna (9-13 r.ż.) - akceptacja kodeksu norm wyznawanych przez grupę, bez przypisywania jako własnych; jest zasadnicza dla moralności partykularystycznej (prowincjonalizm wzorów, zasad, norm postępowania) oraz dla konwencjonalizmu (to postępowanie oparte na umowie, k. grzecznościowy, k. formalny); http://www.slownik-online.pl/ kopalinski, [dostęp: 27.11.2018].

28 Autonomia moralna (13-21 r.ż.) - postępowanie umotywowane wewnętrznie akceptacją norm i uznaniem ich za własne; fazy: pryncypializm (13-15 r.ż., internalizacja zewn. wzorów we własne postawy wyznaczające zachowanie); racjonalizm (15-17 r.ż., szukanie sensu uprzednio zaakceptowanych norm, analizowanie przyczyn potrzeby przestrzegania norm i ich celów) i faza idealizmu moralnego (17-21r.ż., moralność ma charakter świadomy i refleksyjny, problemy moralne są rozstrzygane z punktu widzenia przyjętego systemu wartości, orientacja na cele społeczne a układem odniesienia są ideały i wiedza); http://pl.wikipedia.org/wiki/Rozw\%C3\%B3j_moralny, [dostęp: 27.11.2018].

${ }^{29}$ J. Szurzykiewicz Agresja i przemoc w szkole, [w:] Pedagogika. Podręcznik akademicki, cz. II, red. Z. Kwieciński, B. Śliwerski, Warszawa 2004, s. 280.

30 Tamże, s. 281. 
wiska lokalnego oraz osób z nią powiązanych w dłuższej przestrzeni czasowej, kilkuletniej. L. Pytka wręcz uważa, że tworzą ją dwa komplementarne komponenty: kultura uczenia (się) i społeczny klimat szkoły, najpełniej funkcjonujący w polskiej szkole ${ }^{31}$. Ten klimat, konstruowany uczniowskimi wartościami motywacji do nauki, przekonaniem do własnej szkoły, akceptacją wartości edukacyjnych jest odpowiedzialny za uczniowską świadomość przynależności do społeczności szkolnej, wspólnoty społecznej, w której patologie szkolne wynikają z dysonansów poznawczych, niezrozumienia rzeczywistości szkolnej, niedojrzałości edukacyjnej, niewystarczającego wsparcia ze strony społeczności rówieśniczej. W szkolnej działalności edukacyjnej najistotniejsze okazują się: wykształcenie uczniowskich kompetencji społecznych, długofalowe przedsięwzięcia wychowawczo-korekcyjne, wielopoziomowa prewencja szkoła - klasa - uczeń, a nade wszystko edukacja społeczna w szkole i o szkole dla lokalnej społeczności.

Nauczyciel powinien umieć aranżować wychowawczo sytuacje, w których $\mathrm{w}$ równym stopniu uświadamia sobie i ceni wartość każdej z nich, kształtując tym samym u swoich uczniów wartość tolerancji, umiejętność oceny posiadanego dziedzictwa, z jednoczesnym zwróceniem uwagi na jej niedoskonałości. Niezrozumienie uczniów buntujących się wobec nieznanego, nieakceptowanego i niezrozumiałego zawsze będzie generować kolejne ogniwo łańcucha społecznego wykluczenia. Proces kształcenia jest osadzony na wartościach, które uczniowie mogą rozpoznać, zrozumieć, zaakceptować i (respektować) identyfikować się z nimi oraz dokonywać ich transpozycji we własny proces aksjologicznego dojrzewania.

Dokonujące się na naszych oczach, na przestrzeni jednego pokolenia, zmiany cywilizacyjne redagują coraz więcej pytań wobec zasadności znacząco większych i trudniejszych społecznych oczekiwań wobec nauczycieli. Wiedza pedagogiczna zdobywana podczas kształcenia akademickiego, praktyka zawodowa nabywana w określonej przestrzeni aglomeracji miejskiej lub wiejskiej stawiają pod znakiem zapytania zasadność konstruowania inwariantu oczekiwań środowisk lokalnych wobec pracujących nauczycieli. Czy dobra znajomość patologii szkolnych, spektrum agresji uczniowskiej oraz nieprawidłowości etyczno-zawodowych nauczających nauczycieli jest współcześnie wystarczająca, by skutecznie i mądrze rozwiązywać coraz to nowe - w sferze emocji, wartości i fizyczności - konflikty dokonujące się w przestrzeni edukacyjnej? W jakim stopniu wiedza i pedagogiczna mądrość dyrektora szkoły, wykształcenie rodziców uczniów uczęszczających do jego placówki, na bieżąco aktualizowane kwalifikacje grona pedagogicznego w edukacji społecznej

${ }^{31}$ L. Pytka, Pedagogika resocjalizacyjna. Wybrane zagadnienia teoretyczne i metodyczne, [w:] Tamże, s. 281. 
mogą stanowić receptę społeczną stanowiącą o sukcesie wychowawczym określonej placówki szkolnej?

Skutecznym wsparciem rozwiązywania problemów nieustannie żywej i bolesnej strony dojrzewania szkolnego oraz społecznego uczniów, problemów pracy nauczyciela $\mathrm{w}$ przestrzeni patologii edukacyjnych może w przyszłości okazać się stosowanie zasad przywództwa edukacyjnego w środowiskach uczniowskim i nauczycielskim, zjawiska dobrze rozpoznanego, zrozumianego, zaakceptowanego i respektowanego.

\section{BIBLIOGRAFIA}

Dąbrowska-Bąk M., Przemoc w szkole: analiza wychowania opresyjnego, Ośrodek Wydawnictw Naukowych, Poznań 1995.

Dudzikowa M., O trudnej sztuce tworzenia samego siebie, Wydawnictwo Nasza Księgarnia, Warszawa 1985.

Dyka F., Osobowość nauczyciela wychowawcy, Edukacja i Dialog, 1999, 3.

Gauzy-Steinke H., Relacje nauczyciel - uczeń a norma wzajemności, Auxilium Sociale Novum, 2008, 1-2.

Gurycka A., Błąd w wychowaniu, Wydawnictwa Szkolne i Pedagogiczne, Warszawa 1990.

http://pl.wikipedia.org/wiki/Rozw\%C3\%B3j_moralny, [dostęp: 27.11.2018].

http://pl.wikipedia.org/wiki/Rozw\%C3\%B3j_moralny, [dostęp: 27.11.2018].

http://www.slownik-online.pl/kopalinski, [dostęp: 27.11.2018].

Izdebska H., Błędy wychowawcze, [w:] Encyklopedia pedagogiczna, red. W. Pomykało, Wydawnictwo Fundacja Innowacja, Warszawa 1997.

Jochan S., Zjawiska agresji i przemocy w klasach IV - VI szkoty podstawowej, praca magisterska (promotor: prof. UAM dr hab. Mirosław J. Śmiałek), WPA UAM, Kalisz 2009.

Kołakowski L., Mini wykłady o maxi sprawach, Wydawnictwo Znak, Kraków 2008.

Kruszko K., Między uczniem a nauczycielem, Życie Szkoły, 2006, 1.

Krzywosz-Rynkiewicz B., Ocena szkolna a ksztattowanie kompetencji zawodowych, [w:] Nauczyciel i uczeń w przestrzeniach szkoty, red. M. Nowicka, Wydawnictwo Uniwersytetu Warmińsko-Mazurskiego, Olsztyn 2002.

Lubowiecka J., Wielowymiarowe konteksty zawodowej roli nauczyciela, [w:] Nauczyciel i uczeń w przestrzeniach szkoty, red. M. Nowicka, Wydawnictwo Uniwersytetu Warmińsko-Mazurskiego, Olsztyn 2002.

Ludwiczyński A., Wdrażanie ocen pracowniczych, [w:] Zarzadzanie zasobami ludzkimi, red. H. Król, A. Ludwiczyński, Wydawnictwo Naukowe PWN, Warszawa 2007.

Marek Z.SJ, Pedagogika towarzyszenia, Wydawnictwo Naukowe Akademii Ignatianum, Kraków 2017.

Maruszewski T., Psychologia poznania, Gdańskie Wydawnictwo Psychologiczne, Gdańsk 2001.

Mikiewicz P., Nauczyciel jako istotny aktor społecznego świata szkoty [w:] Nauczyciel: misja czy zawód? Społeczne i profesjonalne aspekty ról, red. P. Rudnicki, B. Kutrowska, M. NowakDziemianowicz, Wydawnictwo Naukowe Dolnośląskiej Szkoły Wyższej, Wrocław 2008.

Obuchowska J., Dynamika nerwic. Psychologiczne aspekty zaburzeń nerwicowych u dzieci i mtodzieży, Państwowe Wydawnictwo Naukowe, Warszawa 1983. 
Obuchowska J., Lęk szkolny, [w] Encyklopedia pedagogiczna, red. W. Pomykało, Wydawnictwo Fundacja Innowacja, Warszawa 1993.

Pytka L., Pedagogika resocjalizacyjna. Wybrane zagadnienia teoretyczne i metodyczne, [w:] Pedagogika. Podręcznik akademicki, cz. II, red. Z. Kwieciński, B. Śliwerski, Wydawnictwo Naukowe PWN, Warszawa 2004.

Raport programu społecznego „Szkoła bez przemocy. Raport roczny 2009, http:/ / www.szkolabezprzemocy.pl/pliki/176-raport-roczny-2009.pdf, [dostęp: 27.11.2018].

Szurzykiewicz J., Agresja i przemoc w szkole, [w:] Pedagogika. Podręcznik akademicki, cz. II, red. Z. Kwieciński, B. Śliwerski, Wydawnictwo Naukowe PWN, Warszawa 2004.

Wysocka E., Encyklopedia pedagogiczna XXI wieku, t. I, Wydawnictwo Akademickie Żak, Warszawa 2003. 